\title{
An Empirical Study: The Effect of Performance Incentives, Internal Control System, Organizational Culture, on Fraud of Indonesia Government Officer
}

\author{
Dwi Asih Surjandari \\ Economic and Business Faculty Mercubuana University \\ Email: dwiasihsurjandari@yahoo.com \\ Irma Martaningtyas \\ Pasca Sarjana Graduate Mercubuana University \\ Email: earma.nich@yahoo.com
}

Doi:10.5901/mjss.2015.v6n5s5p71

\section{Abstract}

The aims of this study is to explore the effect the Performance Incentives, the Internal Control System, the Organization's Culture on Fraud in Directorate of X1 Ministry of X, Indonesia Republic Government . The Data collection used questioner, stratified random sampling and Structural Equation Modeling. Two results were opposite with previous studies,:a) the performance insentive did not affect the fraud, because the incentive did not based on performance instead of its level, most of fraud was done by those with below 5 year working period which most responden came from its level.b) internal control system did not affect the fraud, because application of internal control did not confirm with PP number 60, year 2008 as a good guidance and most fraud done because of opportunity presence. The Organizational Culture, only one in line with previous studies had effected the Fraud, because of succed in punishment socialization, officer training, transparance and accountability.

Keywords: Performance Insentive, System of Internal Control, Organization's Culture and Fraud

\section{Introduction}

Promoting Good Governance is one of many guiding principles in applying sustainable development strategy (Blair, Tony, 2005) and prevention or eliminating fraud/corruption is the one kind of an action of good governance. Fraud elimination is one of some big problems facing Indonesia, recently which appeared from so many fraud cases involved government officers in any level and department presumed that fraud in Indonesia has been a "culture". The serious efforts has been done by government, one of its is giving Incentive Performance gradually for all government officers in all departments and institutions starting from year 2007 (KMK, 2007),(Adkingpro, 2013). Another effort by increasing internal control system through forming institution that prevent, take action against and evaluation fraud action like BPK (Financial Inspection Institution), KPK (Commssion against Corruption)(2013) and increasing organization culture through transparance and education. Although all efforts has been explored, on average corruptions cases still has increasing trend from year to year. And the most cases found in departments and institutions, amounting 126 cases from 286 cases $(\mathrm{KPK}, 2013)$. Empirical evidence came from Singapura and Hongkong that succeed in corruption elimination by empowering internal control system and organization culture especially for public sector by doing transparence, education, punished and reward, meanwhile Swedia by increasing the renumeration for their officers.

\section{Literature Review}

\subsection{Good Governance and Corruption Elimination Strategy}

Governance is "theway state power is used in managing economic and social resources for developmet of society"(World Bank), "the exercise of political,economic, and administrative authority to manage a nation's affair at all levels". (UNDP in Osborne and Gaebler, 2008). World Bank (1997) in Azyumardi Azra (2002) suggested a comprehensive corruption elimination strategy in 3 components.First, is to build bureaucracy based on the stated law with renumeration structure that take into account the officer honesty. The recruitment using merit and promotion system has to be empowered for 
preventing political intervention. A credible financial control has to be employed for preventing the arbritary using of public fund. Second, close all possibilities way for officers to make corruption acts by reducing their full authority in forming policies or in managing finance. Third, to maintain the accountability for government officers and running punishment mechanism. Anti corruption institutions and public is required to empower their control and inspections.

\subsection{FRAUD}

Fraud covers robbery, extortion/exploitation, embezzling, fraudulent, destroying something with intention , (Theodorus M, 2010, KUHP). Fraud could be in the form of Corruption, Asset Misappropriation dan Farudulent Statement (ACFE). Corruption is position or occupation mis using for private interest in the form of Conflict of interest , Briberry, Illegal Gratuities dan Economic Extortion. The causal factors of Fraud as Donald Cressey in Fraud Triangle are : pressure, rationalization, knowledge and opportunity.(Theodorus $\mathrm{M}, 2010$ )

Pressure could be come from financial or social factor. Rationalization is the most crucial fraud component by which Frauder look for justification for their actions. Knowledge dan opportunity hold by the Frauder in order to make it hard to find their actions. There are 2 opportunity components as Donald stated, a) General Information and b) Technical Skill. Meanwile. The factor that could become opportunity availability is the weakness of internal control system. There are many examples of type of fraud stated by Sawyer (2008).

\subsection{Performance Incentives}

There are many definitions about compensations as follows: a) "Compensationis what employees receive in exchange for their contribution to the organization". Sancoko (2010:43-51), Werther and Davis (1996), b) compensation is all the thing that employee received as a counter of their service (Handoko, 1991). c) The sum totalof payments, direct and indirect that an employee isgiven in exchange for service provided. There may be as many as five elements, including: base pay, shortterm incentives, long-term incentives, benefits, and perquisites." ( Deluca, 1993). "Compensation refers to every type of reward that individuals receive in return for their labor".(Mondy and Noe, 1993). e) Mondy and Noe (1993) stated : "Compensation refers to every type of reward that individuals receive in return for their labor".( Mondy and Noe, Milkovich dan Newman (2002).Sugeng Budianto (2012) using performance incentive and salary as renumeration variable indicator, meanwhile Bambang Sancoko (2010) declared about renumeration value indicators. The exstending Performance Incentives is an action in order to raise the employee welfare as such that could be diminished the Fraud level. Swedia has succeed reducing Fraud by delivering performance incentives to their officers.

\subsection{Internal Control System}

Internal control comprises the plan of organization and all of the coordinate methods and measures adopted within a business to safeguard its assets, check theaccuracy and reliability of its accounting data, promote operational efflciency, andencourage adherencp to prescribedmanagerial policies American Institute of Certifield Public Accountant (AICPA).

COSO (The Committee of Sponsoring Organizations of The Treadway Commission) in September 1992, announced a comprehensive structure of control that covered risk management, by redefined internal control in 5 components which related each other. There are: 1.control environment, 2. risk assessment, 3. control activities, 4. information and communication dan 5. Monitoring. This concept adopted by Indonesia Government (PP 60 year 2008). Recent studies by Hermiyati (2010) and Anik Fatun (2013), Singapura and Hongkong had proved that there is negative correlation between internal control effectiveness and fraud.

\subsection{Organization Culture}

Robbins (2006) explained organization culture is committed value system that followed by the member of organization which will differ with the other organization. There are some steps for creating the best employee for sound organization culture. First, Selection, Training and Sosialization, Structural Design, Empowerment and Leadership. Leadership is one important indicator in increasing organization culture because the leadership style influences the running of the organization. Yuki (1981) stated 4 wanted leader actions that could raise organization culture, the leader that: a) supports and does care to employee about their needed and welfare, b) direct, and using planning, organizing, control and coordinazion in his/her command, c) result achievement orientation and d) partisipatif. Second, Performance Evaluation and Third, Reward Sistem. A sound organization culture will have big opportunity in decreasing Fraud as Fatun (2013) 
and practice executed by Singapura and Hongkong..

\subsection{Variables Correlation}

The strategy for Fraud elimination should be done by constructing beaurocracy based on the law and fair payroll (M Theodorus, 2010)(World Bank, 1997 in Azyumardi Azza, 2002) applied succed in swedia, uphold the accountability and the law supremation for government (World Bank ,1997) in Azyumardi Azra (2002). Singapura dan Hongkong was succeed with good governance, internal control system, organization culture, transparence, education and reward (LAN) (BAPPENAS) Stephen P Robbins (2006).

$\mathrm{H} 1$ : There is negative correlation between Performance Incentives and Fraud

$\mathrm{H} 2$ : There is negative correlation between Internal Control System and Fraud H3: There is negative correlation between Organization Culture and Fraud

\section{Methodology (Variables, Dimensions and Indicators)}

The questionnaire was designed to collect empirical data based on previous researches. The indicators for Incentive performance was adopted from Sancoko (2010), Nugroho (2012), and Muryanto (2011), The Internal Control System from COSO (1992) modified by Indonesia government stated on PP 60 (2008), Organization culture from Robbins (2006) and BAPPENAS (2006), Fraud and Types of Fraud based on Fraud Triangle and Sawyer (2008). Performance Incentive Variable (Tukin) used financial dimension referred that performance incentive is what what the dollar amount employee receive as their contribution to the organization with indicators as follows: a) Renumeration compared with other government unit (TK1), b) Renumeration compared with the performance presence (TK2), c) Renumeration compared with the seniority in employee list (TK3), d) Renumeration compared with the experience (TK4), e) Renumeration compared with the grade level (TK5), f) Renumeration compared with their potential assessed (TK6) and g) Renumeration compare with fulfilling their need (TK7). Internal Control Variable (SPI) consist of 5 dimensions and indicators as: a) Control Environment Dimension (LKPDL). The indicators was 1) Ethic Value and Integrity Upholder (SPI1), 2) Organization Strcture Formulation conforming with the Need (SPI2), 3) the Right Delegation of Responsibility and Authorization (SPI3), 4) the Sound of Formulating and Application Policy (SPI4), 5) the effective role of internal control auditor (SPI5) and 6) the presence of effective government (SPI6), b) Risk Valuation Dimension (Resiko) with indicatos as Risk Identification (SPI7) and Risk Analysis (SPI8), c) Control Activity Dimension (Aktiv). With indicators was: The review on the performance of a stated unit government (SPI9), The Controlling on Inormation System Management (SPI10), Physical Control on Asset (SPI11), Formulating and Review on Indicator and performance measure (SPI12), Function Separation (SPI13), The Otorization on Transaction and exstra ordinary event (SPI14), Accurate and on time recording on Transaction ( SPI15), Access Limitation on Assests and its Records (SPI16) and A good Documentation on internal control system, transaction and exstra ordinary event (SPI17), d) Communication and Information Dimension (Infokom), the indicators was the presence and using of all communication equipment (SPI18), continually manage, improve and update information system (SPI19), e) internal control system monitoring dimension (Monitor) with continually monitoring (SPI20), separation evaluation (SPI21) and the follow up of review and audit report (SPI22). Organization Culture Variable (Kultur) with 6 dimensions. 1. Selection Dimension. The indicators was The trasparance of employee selection system (KO1) and Competence Employee Criteria Selection (KO2), 2.Sosialization and Trainning Dimension (Latih), with indicatos as socialization of punishment of fraud (KO3) and trainning for employee competence updating (KO4).3. Leadership Dimension (pimpin) with indicators as supporting leadership (KO5), direction leadership (KO6) ,result goal orientation leadership (KO7) partisipative leadership (KO8). 4.Transparance Dimension (Transp) with indicators as information access opened for stake holder (KO9) and the sufficient information for stake holder monitoring

(KO10). 5. Accountability Dimension (Akunt) with indicators as the policy conformity with the stated rule (KO11). 6. The Law supremation dimension (Hukum) with indicator as the application of punishment and reward that in line with the stated rule (KO12). Fraud variable ( Fraud )with fraud reason factor dimension (pnybab) and the indicators as follows: 1) Pressure (FR1), 2) Rasionalisazation (FR2), 3) Getting knowledge from other people (FR3)and 4) The presence of opportunity (FR4). By using Warp PLS program and SEM-PLS Second-Order Construct analysis appeared in Figure 1 below. 


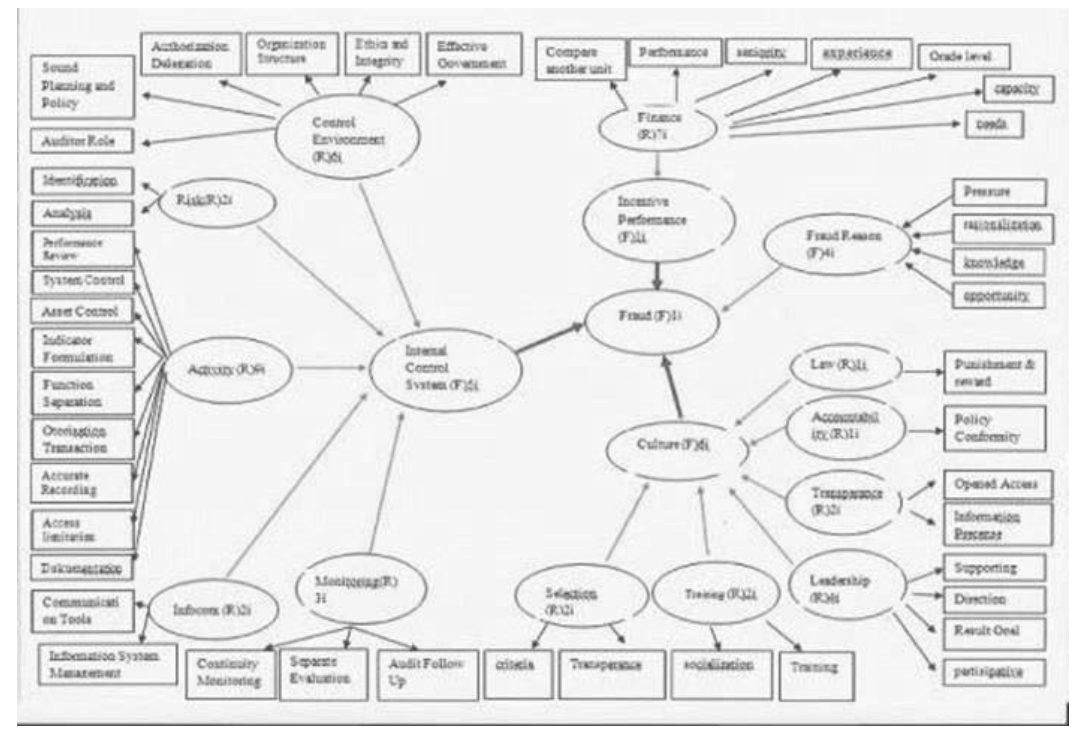

Figure 1. Variables, Dimensions and Indicators, Second Order Construct

\section{Data Collection}

The population was all government officer in Directorate X1, Department X the government of Indonesia Republic which was choosed with stratified random sampling with strata sample group based on 7 level, 134 people on the population and 51 sample of its. All measurement used was ordinal scale. The returned questionnaire was 48 from 51, so 82.23\%. The most respondent, $85 \%$ was came from the lowest level

\section{Data Analysis and Results}

\subsection{Descriptive Statistic}

In responding about Type of Fraud was found that the most type of Fraud that had been done is forgery or stamp which was executed by most by those whose has worked not more than 5 years In responding of the reason behind Fraud made, the results showed that the reason behind Fraud made was because of the pressure from third parties and the presence of opportunity. In responding of the application of Internal Control System , most respondents answered that it was not confirm with government guidance. In responding of Organization Culture Questions, 30\% stated confirm.. 27\% answered that Fraud Sosialization and Trainning was conform, 16\% was the most confom. 35\% stated that the leadership in Directorate X1 was good. 39\% stated that there was an information opennes. $48 \%$ stated that there was a conformity between implementation public policy arrangement with the stated rule and law. And only $22 \%$ declared that punishment Reward, had been applied.

\subsection{SEM Analysis}

The SEM program was running until the data was valid and no multikolinearity with loading $>0.70$, and $p$ value $<0.05$ VIF $<$ 3.3. As required. The result was model fit,The Reliabilities measured by Composite reliability value cronbach alpha $>0.70(0.60-0.70$ is available $)$. 


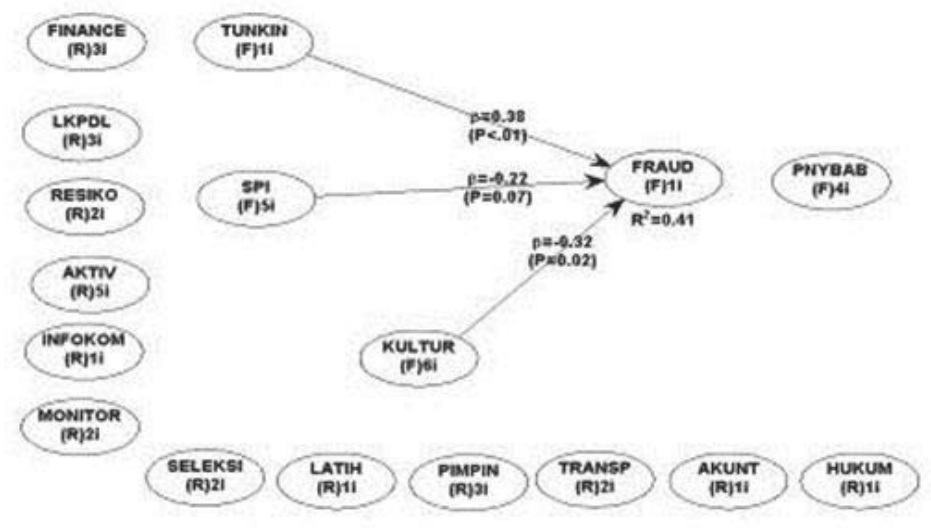

Figure 2. Research Construct Model

Tabel 1. Model Fit Analysis

\begin{tabular}{lccl}
\hline & Requisite & Counting & Conclusion \\
\hline$p$-values average path coefficient ( APC ) & $<0.05$ & $<0.001$ & Significant \\
$p$-values Average R-Squared ( ARS ) & $<0.05$ & 0.044 & Significant \\
Average Variance Inflation Factor ( AVIF ) & $<5$ & 1.084 & No multikolinearities \\
\hline
\end{tabular}

\section{Hyphotesis Testing}

$\mathrm{H} 1$ : There is negative correlation between Incentive Performance and Fraud, rejected, $p$-value calculation $<0.01$, it was $<0.05$, it was significant, path coefficient was 0.38 , positive correlation, effect size for path coefficient 0.181 so the influence of predictor latent variable was weak.

$\mathrm{H} 2$ : There is a negartive correlation between Internal Control and Fraud , rejected

$p$-value calculation $=0.07>$ Requisite $p$-value was $<0.05$, not significant, path coefficient -0.22 was negative correlation, effect size for path coefficient 0.084 , the influence of predictor latent variable was weak

H3: There is a negative correlation between Organization Culture and Fraud, accepted

$p$-value calculation $=0.02<0.05$, significant, path coefficient -0.32 , negative correlation, effect size for path coefficient 0.142 , the influence of predictor latent variable was medium.

R-squared value was 0.407 , fraud construct could explain only $40,7 \%$ Q-Squared was 0.413 , the prediktif was valid because it was $>0$.

\section{Conclusions and Managerial Implications and Recomendations}

\subsection{Conclusion}

For Performance Incentives and Fraud, result showed a weak significant positive correlation, this meant the correlation between is weak, it was not line with World Bank recommendation and prior research. The performance incentive has been given based on its level, the higher the level the more the incentive they got. The most respondent came from the lowest level (81\%), and the reason behind Fraud was pressure by third party (the Higher level), and that most (50\%) be done by officer below 5 year working period with the most type was Forgery and/or Stamp. That is why it was rejected.

There was no negative correlation between Internal Control System and Fraud, it was opposite with recommendation World Bank and prior research. Research found that the application of Internal Control system not confirmed with PP number 602008 and 38\% of Respondent stated that Fraud was done because of the presence of Opportunity. That is why it was rejected. There was negative correlation between Organization Culture and Fraud, it was in line with World Bank and prior research, most respondent stated that the government succeed in doing socialization of punishment, training for up date officer competence, information transpparency and accountability but still lack in 
conformity of punishment and reward also selection in officer recruitment. That is why it was accepted. The type of Fraud that was done by government officers were Forgery and/or Stamp, Taken away Office Equipment, Taken away small Box of Money, not record a Transaction and take away the money, record un properly or not accurate and manipulation in quantity and price material purchased, doing purchased which not confirm with the specification. The most type was Forgery and/or Stamp.

\subsection{Implications and Suggestions}

This findings could give a contribution for government to make evaluation in Performance Incentive not only based to the level of officer also take into account the competence, seniority, honesty, fairness distribution and the performance it self. Government also suggested to make a tight control in Forgery and/or Stamps processes as well as other type of Frauds that happened. In Internal Control System, government has to make sure that the application must be in line with the government standard in order to reduce the Opportunity for doing Fraud as research finding. This application could include the empowering of all institution and public interest on Fraud. In Organization Culture, government could continue the presence program (include leadership acceleration) but also take into account about the conformity between reward and punishment and the fairness of officer selection program. The Variables used in this model only could explain $40.70 \%$ the effect of those on fraud. The rest, $59.3 \%$ affected by other variables that not included such as religion perspective and asimmetry information.It was also suggested to make study in other department, especially on those with higher record of Fraud, such as Tax Office.

\section{References}

Adkingpro. (2013). Daftar K/L yang menerima Tunjangan Kinerja. Online Available : World Wide Web : http://www.setagu.net (Dec $4,2013)$

Azra, Azyumardi. (2002). Korupsi dalam Perspektif Good Governance, Jurnal Kriminologi Indonesia, 2 (1), 31 - 36.

Blair, Tony, Securing The Future Delivering UK Sustainable Development Strategy, 2005, HMSO St Clement House, 2-16, Colegate, Norwich, NR3, 1 BQ,UK

Boedianto, Sugeng. (2012). remunerasi, sasaran kinerja dan peningkatan kinerja pegawai LAPAS kelas IIA anak Blitar, Jurnal IImu Manajemen, REVITALISASI, 1 (3), - .

Badan Pemeriksa Keuangan. (2011). IHPS I Tahun 2011. (2011). IHPS II Tahun 2011. (2012). IHPS I Tahun 2012.(2012). IHPS II Tahun 2012.(2013). IHPS I Th 2013.

Badan Perencanaan Pembangunan Nasional. (2006). Empat Belas Karakteristik Tata Kelola Pemerintahan Yang Baik.

Fatun, Anik. (2013). Faktor-faktor yang mempengaruhi kecenderungan kecurangan (Fraud). (-).

Handoko,Hani (1991) Manajemen Personalia dan Sumber Daya Manusia, BPFE Jogjakarta

Hermiyetti. (-). Pengaruh Penerapan Pengendalian Internal Terhadap Pencegahan Fraud Pengadaan Barang dan Jasa. (-)

Hidayat, Noermayanti. (2010). Pemodelan Structural Equation Modeling (SEM) Berbasis Varians Pada Derajat Kesehatan Di Propinsi Jawa Timur 2010. Seminar Nasional Penelitian,Pendidikan dan Penerapan MIPA, Yogyakarta, Juni 2010. (-)

Indriantoro,Nur. (1999). Metodologi Penelitian Bisnis Untuk Akuntansi dan Manajemen. Yogyakarta: BPFE

Keputusan Menteri Keuangan. (2007). Kepmenkeu No. 289/KMK.01/2007 tentang Tunjangan Khusus Pembinaan Keuangan Negara.

Komisi Pemberantasan Korupsi. (2013). Data Penanganan Korupsi Berdasarkan Instansi Tahun 2004-2013 (per 30 September 2013). Diakses pada 3 Desember 2013 dari World Wide Web : http://www.kpk.go.id

Komisi Pemberantasan Korupsi. (2013). Data Jenis Perkara Korupsi Tahun 2004-2013 (per 30 September 2013). Diakses pada 3 Desember 2013 dari World Wide Web : http://www.kpk.go.id

Lembaga Administrasi Negara. (2007). Strategi Penanganan Korupsi di Negara-Negara Asia Pasifik. (-).

Mondy,R Wayne, Noe,Robert M,Premaux, Shane R.(1993) Human Resources Management, Pearson Education International

Muryanto, Eko. (-). Pengaruh kompensasi terhadap kinerja dengan motivasi sebagai variabel moderating. (-).

Osborne, David \& Gaebler, Ted (1992).Re inventing Government, How The Entrepreneurial Spirit is Transforming The Public Sector, Addison-Wesley,USA

Peraturan Pemerintah. (2008). Peraturan Pemerintah Nomor 60 Tahun 2008 tentang Sistem Pengendalian Intern Pemerintah.

Peraturan Presiden. (2013). Peraturan Presiden Nomor 90. 2013 tentang Daftar Tunjangan Kinerja Kementerian Perhubungan

Robbins, P. Stephen. (2006). Perilaku Organisasi. Klaten : PT. Intan Sejati.

Sancoko, Bambang. (2010). remunerasi terhadap peningkatan pelayanan public di KPPN Pratama I. Bisnis \& Birokrasi Jurnal IImu Administrasi dan Organisasi -. (43-51).

Theodorus, M. (2010). Akuntansi Forensik dan Audit Investigatif. Jakarta : Salemba Empat.

Werther, William B Jr, Davis, Keith,A (1996) Human Resources and Personnel Management, Mc Graw Hill

Yuki, A.Gary. (1981). Leadership in Organization. Enlewood Cliff, N.J : Prentice-Hall 